\author{
육계분 - 제과부산물 혼합사료 급여가 육성 거세 한우의 생산성, \\ 경제성 및 육 특성에 미치는 영향 \\ 곽완섭*.윤정식*정근기** \\ 건국대학교 자연과학대학 생명자원환경과학부 축산학전공* \\ 영남대학교 자연자원대학 생물자원학부 동물생명과학전공**
}

\title{
Effect of Feeding Broiler Litter and Bakery By-product Ration on Production, Economy and Meat Quality of Growing Hanwoo Steers
}

\author{
W. S. Kwak*, J. S. Yoon* and K. K. Jung** \\ Animal Science, School of Life Resource and Environmental Sciences, \\ College of Natural Sciences, Konkuk University*, \\ Danwol-dong 322, Chung-Ju, Chung-Buk, Korea 380-701 \\ Dept. of Animal and Life Science, College of Natural Resources, Yeungnam University,** \\ Kyung-San, Kyung-Buk, Korea

\begin{abstract}
This study was conducted to determine the effect of feeding a mixture of broiler litter and bakery by-product on production, economy and meat characteristics of growing 'Hanwoo' steers. A control diet (conventional formulated feed and rice straw) and a treatment $\operatorname{diet}(90 \%$ mixture of broiler litter $64 \%$ and bakery by-product $36 \%$ and $10 \%$ rice straw on DM basis) were prepared on an isoenergetic basis and fed to 20 steers for 12 weeks. Palatability of TMR by 'Hanwoo' was fair. Compared with feeding a control diet, feeding a treatment diet resulted in increased( $(\mathrm{l}<0.05) \mathrm{DM}$ intake, similar OM intake, similar daily weight gain $(0.75$ vs $0.64 \mathrm{~kg} / \mathrm{d})$ and feed efficiency of $\mathrm{DM}(10.1$ vs 12.5$)$ and $\mathrm{OM}(9.0$ vs 10.6), considerably $(45 \%)$ reduced(I $<0.05)$ feed cost/gain, and similar meat characteristics. These results show that a mixed ration manufactured with broiler litter and bakery by-product may be potentially used for growing 'Hanwoo' steers.
\end{abstract}

(Key words : Broiler litter, Bakery by-product, Cattle, Production, Meat)

$\begin{array}{cl}\mathrm{I} \text { 서 론 } & \begin{array}{c}\text { 급여에 따른 양축농가의 노동력 부족 해소와 } \\ \text { 반추가축의 생산성 향상 및 사료비 부담 경감 }\end{array} \\ \text { 우리나라에서는 농후사료와 조사료의 분리 } & \text { 을 위해서 1993년부터 영농조합법인 등의 생산 }\end{array}$

“본 연구는 농림부 기획연구 지원에 의해 수행되었음”

Corresponding author : Dr. W. S. Kwak, School of Life Resource and Environmental Sciences, College of Natural Sciences, Konkuk University, Chung-Ju, Chung-Buk, 380-701, Korea. Tel:82-43-840-3521 Fax:82-43-851-8675, E-mail:wsk@kku.ac.kr 
자 단체와 $\mathrm{TMR}$ 제조업체 등에 $\mathrm{TMR}$ 제조시설 설치비를 지원해 주고 있다. 그리고 농산부산 물 및 식품부산물 등 부존 자원을 유휴 노동 력의 이용을 통한 재활용 극대화와 사료비 절감 목적을 동시에 달성키 위해서 정부는 자가 배합사료 생산에 필요한 혼합기, 분쇄 기 등의 장비와 제조시설을 지원해주고 있다 (노, 2001). 이러한 시점에서 언제 어디서나 쉽게 구할 수 있는 부존사료자원으로서 육계 분과 제과부산물만을 이용한 혼합사료의 제 조 연구가 국내외적으로는 처음으로 수행되 었다.

본 연구와 유사한 혼합사료 동물사양 연구 로서, 미국 알라바마주 연구팀(McCaskey 등, 1994a,b)은 육성비육우에게 육계분-옥수수알 곡(50 : 50) 발효사료를 급여하였을 때 기존 사료 급여 시와 비교해서 생산성은 별 차이가 없으면서, 상당한(30 1\%) 사료비 절감효과 를 누릴 수 있었다고 보고하였다. 이는 육계 분은 전체사료의 단미사료 원료로서 상당량 이용할 수 있음을 의미한다. 그리고 식품부산 물로서의 제과부산물은 단미사료 원료로서 소 사료의 $30 \%$ 까지는 아무런 기호성 문제없이 급여할 수 있는 것으로 알려져 있으며 (Ensminger 등, 1990), 제과부산물을 거세 비육 우에게 급여 시 증체율과 도체 및 육질 특성 에 뚜렷한 차이 없이 기존의 옥수수알곡 $75 \%$ 와 대두박 $65 \%$ 를 대체할 수 있었다고 하였다 (Guiroy 등, 2000). 옥수수알곡을 대체하면서 사료 건물의 $30 \%$ 까지 건조 제과부산물을 급 여할 때 건물과 유기물 섭취량 및 장쇄 지방 산과 섬유소 소화율은 감소하고, 증체율과 사 료효율은 비슷하며, 갈비 지방 두께는 증가하 는 것으로 나타나, 결과적으로 적정 급여량은 $30 \%$ 이하인 것으로 보고되었다(Milton과 Brandt, 1994). 이러한 결과를 종합해볼 때 고 단백질 조사료 원인 육계분과 고에너지 원인 제과부산물만으로 제조된 혼합사료는 육성 . 비육우용 사료로서 충분한 잠재적 이용 가능 성이 있을 것으로 가정되었다.

따라서, 본 연구는 제조된 육계분-제과부산 물 혼합사료로의 기존 배합사료와 볏짚 대체
시 한우 육성우의 생산성, 경제성 및 육질에 미치는 효과를 구명하고자 수행하였다.

\section{ㅍ 재료 및 방법}

\section{1. 실험 동물 및 처리구}

충북 음성군 소이면 소재 대성농장(음성축협 산하)에서 비슷한 체중의 거세한 육성 한우 20 두(평균체중 $250.6 \mathrm{~kg}$ )를 5두씩 4개 구로 나뉘 어, 2개 구에는 대조구(축협배합사료, 볏짚 급 여구) 사료를, 다른 2 개 구에는 시험구(육계분제과부산물 혼합사료, 볏짚 급여구) 사료를 공 급하였다. 혼합사료는 전 실험(곽 등, 2003)에서 와 같이 육계분을 퇴적발효시킨 후 한우 급여 전에 제과부산물과 하기한 방법으로 혼합하여 제조하였다. 동물 급여 첫 4주간은 대조구와 시험구 공히 전체 사료를 체중 대비 $2.5 \%$ 수준 에서 공급하였으나, 외관적으로 소들이 소리치 며 배고파하고, 급여 4주째 증체량이 예상보다 다소 낮은 것으로 나타나서, 이 후부터는 공급 량을 $2.8 \%$ 수준으로 상향 조정해 주었다. 즉 대조구의 경우, 배합사료는 체중 대비 $1.6 \%$, 볏 짚은 $1.2 \%$ 수준에서, 시험구는 혼합사료 $2.52 \%$, 볏짚 $0.28 \%$ 수준으로 공급하였다. 유효 섬유소 (effective fiber) 원으로서의 입자도가 큰 건초의 무첨가 시 동물 생산성을 상당히 저하시킬 수 있기 때문에(Rankins, 1995), 볏짚은 diet dry matter(DM)의 $10 \%$ 수준에서 급여하였다. 대조 구의 배합사료와 볏짚 배합 비율과 시험구사료 의 육계분-제과부산물 혼합물[total digestible nutrients(TDN) 69\%로 배합, DM 기준으로 육계 분 64 : 제과부산물 36 비율로 혼합] $90 \%$ 과 볏 짚 $10 \%$ 급여구는 본 육성 한우의 요구량을 충 족시키는, 동일 열량[TDN 66.9\%, 농진청(1992)] 기준으로 맞추어 졌다.

분석된 각 사료원료들의 조성분(Table 1)을 기초로 하여, 대조구 사료와 시험구 사료의 제 조 배합비와 분석된 화학적 성분은 Table 2에 제시되었다. 대조구와 비교해서 시험구는 $\mathrm{DM}$ 이 약 $10 \%$, organic matter(OM)이 약 $5 \%$ 낮았 
으며, crude protein(CP)는 5\%, ether extract(EE)

는 2 배정도, 조회분은 $5 \%$ 높고, fiber는 훨씬 낮은 편이었다. 그리고 $\mathrm{CP}$ 중 non-protein $\mathrm{N}(\mathrm{NPN})$ 성분비는 시험구에서 배 이상 높았다.

사양 실험은 2001년 2월 3일에 최초 체중 측 정을 하여 시작한 후, 4주 경과 시(3월 3일)에 2차 무게 측정을 하였으며, 12주째(4월 28일)에 최종 측정을 하였고, 총 12 주 동안 실시하였다.

\section{2. 시료 채취 및 조성분 분석}

급여 사료의 시료는 매주 1 회씩 사료 급여 전에 적당량을 채취하여 비닐 백에 밀봉한 후 바로 $-20^{\circ} \mathrm{C}$ 뵹동고에 보관하였다. 조성분 분석 을 위하여 시료는 냉장고에서 녹인 다음, $\mathrm{DM}$ 측정 시 배합사료와 볏짚은 $105^{\circ} \mathrm{C}$ 건조 oven에 서 24시간 건조한 후 측정하였고, 혼합사료는 자체 잔존하는 휘발성지방산과 암모니아 등의 건조 중 손실을 예방하기 위해서 $60^{\circ} \mathrm{C}$ 건조 oven에서 48시간 건조한 후 측정하였다. $\mathrm{CP}$, $\mathrm{EE}$, 조회분은 $\mathrm{AOAC}(1990)$ 방법에 따라 분석하

Table 1. Chemical composition(\%) of feedstuffs

\begin{tabular}{lrrr}
\multicolumn{4}{c}{ fed to growing 'Hanwoo' steers $^{1,2)}$} \\
\hline \multicolumn{1}{c}{ Item } & $\begin{array}{c}\text { Formulated } \\
\text { feed }\end{array}$ & $\begin{array}{r}\text { Rice } \\
\text { straw }\end{array}$ & $\begin{array}{r}\text { Mixed } \\
\text { ration }^{3)}\end{array}$ \\
\hline \hline Dry matter & 89.5 & 87.8 & 77.5 \\
Organic matter & 92.0 & 88.2 & 85.1 \\
Ether extract & 3.8 & 0.8 & 5.8 \\
Crude protein & 15.3 & 4.5 & 17.3 \\
$\quad$ True protein & 74.9 & 82.3 & 47.5 \\
$\quad$ NPN & 25.1 & 17.7 & 52.5 \\
$\quad$ ADF-CP & 11.5 & 45.2 & 13.7 \\
Neutral detergent & 35.0 & 78.5 & 32.0 \\
$\quad$ fiber & & & \\
Acid detergent & 18.2 & 54.2 & 21.3 \\
fiber & 16.9 & 24.3 & 10.7 \\
Hemicellulose & 11.9 & 49.9 & 15.9 \\
Cellulose & 3.8 & 4.3 & 5.3 \\
Lignin & 8.0 & 11.9 & 14.9 \\
Crude ash & 78.4 & 48.0 & 69.0 \\
TDN & & & \\
\hline
\end{tabular}

\footnotetext{
1) On DM basis.

${ }^{2)}$ Means of 10 observations.

${ }^{3)}$ Calculated total digestible nutrients.
}

Table 2. Ingredient and chemical compositions of diets ${ }^{1)}$

\begin{tabular}{lcc}
\hline Item & Control & Treatment \\
\hline \hline Ingredient composition, \% & & \\
Formulated feed & 62.2 & - \\
Rice straw(RS) & 37.8 & 10.1 \\
Mixed ration(TMR) & & \\
& - & 89.9 \\
\hline Chemical compositions, \% & & \\
Dry matter & 88.8 & 78.4 \\
Organic matter & 90.5 & 85.4 \\
Ether extract & 2.6 & 5.3 \\
Crude protein & 11.0 & 16.0 \\
$\quad$ True protein & 76.0 & 48.5 \\
$\quad$ NPN & 24.0 & 51.5 \\
$\quad$ ADF-CP & 17.0 & 13.6 \\
Neutral detergent fiber & 52.4 & 36.7 \\
Acid detergent fiber & 32.6 & 24.6 \\
Hemicellulose & 19.8 & 12.1 \\
Cellulose & 28.4 & 19.4 \\
Lignin & 4.2 & 5.2 \\
Crude ash & 9.6 & 14.6 \\
TDN & 66.9 & 66.9 \\
\hline
\end{tabular}

1) On DM basis.

${ }^{2)}$ Broiler litter $64 \%$ : bakery by-product $36 \%$ on DM basis.

${ }^{3)}$ Calculated total digestible nutrients.

였다. 특히 혼합사료의 $\mathrm{CP}$ 는 풍건 상태에서 분 석한 다음 $\mathrm{DM}$ 수치로 보정해 주었다. True protein은 5\% trichloroacetic acid 용액에서 침전 되는 양으로, $\mathrm{NPN}$ 은 $\mathrm{CP}$ 에서 true protein을 뺀 양으로 구하였다. Acid detergent fiber(ADF)-CP 는 시료의 $\mathrm{ADF}$ 를 합쳐서 $\mathrm{CP}$ 성분(AOAC, 1990)을 분석하여 구하였다. Neutral detergent fiber(NDF), ADF, lignin은 Van Soest 등(1991)의 방법에 따라 분석하였다. Hemicelllulose 함량은 $\mathrm{NDF}$ 에서 $\mathrm{ADF}$ 를 뺀 수치로, cellulose 함량은 $\mathrm{ADF}$ 에서 lignin을 뺀 수치로 구하였다.

사료섭취량 측정을 위해서 실험 기간 동안 급여량과 잔량을 매일 측정 기록하였으며, 사 료 효율은 섭취량을 증체량으로 나누어 구하였 다. 조회분-보정(ash-corrected) 사료 효율은 사 
료 유기물 기준으로 계산하였다(Cross와 Jenny, 1975). 또한 건강성 관찰과 경제성 분석(일일 두당 사료비, 증체당 사료비, 시험구 사료의 손 익분기점 가격 등)이 이루어졌다.

12 주의 사양실험 종료 후에는 시험구 급여는 중단되었으며, 1 여년 후 공시 한우 체중 600 $\mathrm{kg}$ 이상에서, 도살 시의 생체중, 육량(지수, 등 급), 육질 등급 및 육질 parameter(등지방 두께, 등심 단면적, 근내 지방도, 육색, 지방색, 조직 감, 성숙도)에 대한 data를 통계 분석하였다.

\section{3. 통계 분석}

모든 통계 분석은 Statistix7(2000)에 의해 분 석되었다. General Linear Model을 이용한 one way analysis of variance를 실시하였다. 평균간 비교를 위해서 studentized t-test를 이용하였다.

\section{III 결과 및 고찰}

\section{1. 급여사료의 성분 변이도}

사료의 화학적 성분상의 높은 변이도는 가축
의 생산성을 떨어뜨리는 한 요인이 될 수 있 다. 실험기간 동안 급여된 혼합사료와 상업적 배합사료의 시료 각각 10 개씩의 화학적 성분 변이도를 분석한 결과(Table 3), 혼합사료의 성 분 변이 지수(coefficiency of variation)는 배합사 료와 비교해서 $\mathrm{DM}, \mathrm{OM}, \mathrm{CP}$, true protein, $\mathrm{NDF}$, $\mathrm{ADF}$, crude ash 등은 높았고, $\mathrm{EE}, \mathrm{NPN}$, cellulose, lignin 등은 비슷하였으며, $\mathrm{ADF}-\mathrm{CP}$ 는 낮았다. 특히 두 사료 공히 $\mathrm{EE}, \mathrm{ADF}-\mathrm{CP}$, hemicellulose, cellulose, lignin 함량의 변이 지수 는 최소 $15.5 \%$ 에서 최대 $39.4 \%$ 로 높은 편이었 다. 전반적으로 주요 화학 성분의 성분 변이 지수는 배합사료는 $10 \%$ 이하, 혼합사료는 $15 \%$ 이하의 수준이었으며, 혼합사료의 높은 성분 변이도는 가축의 생산성에 현저한 악 영향을 미칠 정도는 아닌 것으로 사료되었으나, 불리 하게 작용할 것임은 분명한 사실이었다.

\section{2. 제조된 혼합사료의 섭취 양상}

사료 전환기간 동안 육성 거세 한우의 혼합 사료의 섭취 양상은 Fig. 1에 제시되어져 있다. 사료 풍건물 기준으로 일일 두당 평균 $1.7 \mathrm{~kg}$

Table 3. Variation in chemical composition(\%) of mixed ration and formulated feed fed to growing 'Hanwoo' steers ${ }^{1,2}$

\begin{tabular}{|c|c|c|c|c|c|c|c|c|c|c|}
\hline \multirow{2}{*}{ Item } & \multicolumn{5}{|c|}{ BL-BB Mixture $^{3)}$} & \multicolumn{5}{|c|}{ Formulated feed } \\
\hline & Mean & & nge & SD & $\mathrm{CV}$ & Mean & & nge & SD & $\mathrm{CV}$ \\
\hline Dry matter & 77.5 & 68.0 & -86.5 & 7.0 & 9.1 & 89.5 & 88.4 & -91.5 & 1.1 & 1.3 \\
\hline Organic matter & 85.1 & 81.0 & -87.1 & 1.7 & 2.0 & 92.0 & 90.8 & -93.1 & 0.6 & 0.6 \\
\hline Ether extract & 5.8 & 4.5 & -7.6 & 0.9 & 15.4 & 3.8 & 3.0 & -4.7 & 0.6 & 15.5 \\
\hline Crude protein & 17.3 & 15.1 & -19.6 & 1.7 & 10.1 & 15.3 & 14.7 & -16.1 & 0.4 & 2.7 \\
\hline True protein & 47.5 & 38.6 & -52.1 & 4.8 & 10.1 & 74.9 & 71.4 & -79.1 & 2.4 & 3.2 \\
\hline NPN & 52.5 & 47.9 & -61.4 & 4.8 & 9.2 & 25.1 & 20.9 & -28.6 & 2.4 & 9.6 \\
\hline ADF-CP & 13.7 & 11.3 & -17.9 & 2.0 & 14.7 & 11.5 & 4.0 & -14.3 & 3.1 & 26.8 \\
\hline Neutral detergent fiber & 32.0 & 26.2 & -39.8 & 4.7 & 14.7 & 35.0 & 29.3 & -38.5 & 3.5 & 10.1 \\
\hline Acid detergent fiber & 21.3 & 17.4 & -25.3 & 3.0 & 14.0 & 18.2 & 16.3 & -21.7 & 1.8 & 9.9 \\
\hline Hemicellulose & 10.7 & 4.7 & -15.3 & 4.0 & 37.6 & 16.9 & 13.0 & -21.2 & 2.8 & 16.6 \\
\hline Cellulose & 15.9 & 11.9 & -22.7 & 4.0 & 25.4 & 11.9 & 6.6 & -15.4 & 2.5 & 21.4 \\
\hline Lignin & 5.3 & 2.4 & -7.9 & 1.9 & 35.1 & 3.9 & 1.5 & -5.7 & 1.6 & 39.4 \\
\hline Crude ash & 14.9 & 13.0 & -19.0 & 1.6 & 11.1 & 8.0 & 6.9 & -9.2 & 0.6 & 7.4 \\
\hline
\end{tabular}

${ }^{1)}$ On DM basis.

2) Means of 10 observations(SD=standard deviation, $\mathrm{CV}=$ coefficiency of variation).

${ }^{3)}$ Broiler litter(BL) $64 \%$ : bakery by-product(BB) $36 \%$ on DM basis. 


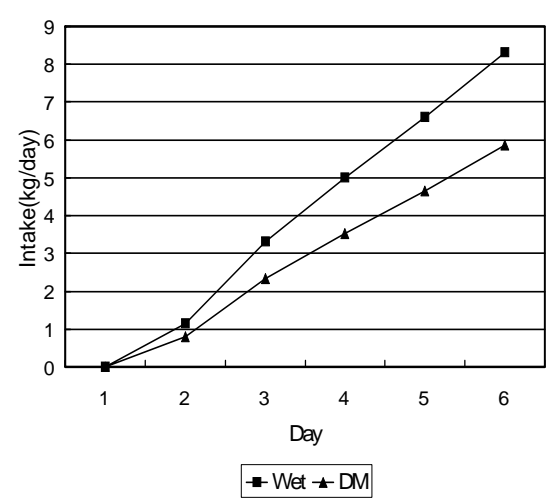

Fig. 1. Daily feed intake pattern of a mixture (broiler litter $64 \%$ : bakery by-product $36 \%$ on DM basis) by growing'Hanwoo' steers during the transition period of $\operatorname{diet}($ ration $\mathrm{DM}=70.6 \%)$

씩 교체하였을 때 잔량은 거의 없었으며, 예정 된 5일 간의 전환기간에 $100 \%$ 교체되었다. 이 는 혼합사료의 기호성에 전혀 문제가 없음을 입증하는 것이다. 대체로 육계분발효사료 자체 에는 기호성 문제가 생길 수 있으나(고 등, 1991; 이와 곽, 1999), 이에 기호성이 좋은 제과 부산물이 혼합되어 제조된 혼합사료는 섭취상 의 문제점을 전혀 보이지 않았다. 즉 육계분발 효사료의 낮은 기호성은 제과부산물의 높은 기 호성에 의해 상쇄되는 효과를 보였다. 단지 기 존의 완전혼합사료에서와 같이 일중 섭취시간 이 길어지는 양상을 보였는데, 이는 양적으로 단시간에 모두 섭취하기에는 다소 많은 분량이 기 때문이었다.

\section{3. 체중변화 및 사료효율}

12주 동안의 사양 시험기간 동안 처리별 사 료 섭취량, 체중 변화 및 사료효율의 결과는 Table 4에 제시되어져 있다. 사료 섭취량(wet 또는 $\mathrm{DM}$ 공히)은 대조구보다 시험구가 약간 높았으나 $(\mathrm{P}<0.05)$, 일일 $\mathrm{OM}$ 섭취량은 거의 동 일하였다. 최초 체중과 최종 체중은 처리구별 로 유의적 차이는 없었다. 대조구와 시험구의 증체량과 일당증체율 및 사료효율은 비슷하였 다. 사료효율은 조회분 보정(ash-corrected) 사료
Table 4. Daily feed intake, body weight(wt) change and feed efficiency of growing 'Hanwoo' steers

\begin{tabular}{lccc}
\hline \multicolumn{1}{c}{ Item } & Control & Treatment $^{1)}$ & $\mathrm{SE}$ \\
\hline \hline Wet feed intake, kg/d & $8.42^{\mathrm{a}}$ & $10.10^{\mathrm{b}}$ & 0.01 \\
Feed DM intake, kg/d & & & \\
$\quad$ Formulated feed & 4.49 & 0 & - \\
$\quad$ Mixed ration & 0 & 7.12 & - \\
$\quad$ Rice straw & 2.99 & 0.80 & - \\
$\quad$ Total & $7.48^{\mathrm{a}}$ & $7.92^{\mathrm{b}}$ & 0.02 \\
Feed OM intake, kg/d & 6.77 & 6.76 & 0.02 \\
Initial body wt, kg & 248.9 & 252.4 & 13.6 \\
Final body wt. kg & 311.6 & 306.1 & 15.3 \\
Wt gain, kg & 62.6 & 53.7 & 6.9 \\
Average daily gain. kg & 0.75 & 0.64 & 0.08 \\
Feed, kg/gain, kg & 10.1 & 12.5 & 1.3 \\
Ash-corrected feed, & & & \\
$\quad$ kg/gain, kg & 9.0 & 10.6 & 1.2 \\
\hline
\end{tabular}

${ }^{1)}$ Mixed ration $90 \%$ : rice straw $10 \%$; mixed ration = Broiler litter.

$64 \%$ : bakery by-product $36 \%$ on DM basis.

${ }^{\mathrm{a}, \mathrm{b}}$ Means with different superscripts within the same row differ $(I<0.05)$.

유기물 효율로 계산하였을 때 더욱 비슷하여 졌다. 약간 낮은 증체율 수치는 혼합사료의 상 대적으로 높은 성분 변이도 또는 혼합사료의 주성분인 육계분의 에너지 수준을 실제보다 과 대평가한 때문일 수도 있다.

\section{4. 경제성}

대조구와 시험구의 경제성을 비교하면(Table 5), 전반적으로 시험구의 사료비가 현저히 낮았 다. 한우 두당 일당 섭취량에 대한 사료비는 대조구와 비교해서 시험구는 약 $53 \%$ 의 사료비 절감 효과가 있었다. 가장 신뢰성 높은 지표인 $1 \mathrm{~kg}$ 증체에 요구되는 사료비용은 대조구와 비 교해서 시험구는 약 $45 \%$ 정도의 획기적 절감 효과를 보였다. 미국 알라바마 연구팀 (McCaskey 등, 1994a,b)에 의하면, 육성비육우에게 육계분옥수수알곡(50 : 50) 발효사료를 급여하였을 때 
Table 5. Economic value of feeding different diets to growing 'Hanwoo' steers ${ }^{1)}$

\begin{tabular}{lccr}
\hline \multicolumn{1}{c}{ Item } & Control & Treatement $^{2}$ & SE \\
\hline \hline Daily feed cost/head, won & $1,723^{\mathrm{a}}$ & $808^{\mathrm{b}}$ & 2 \\
Feed cost/gain, won/kg & $2,328^{\mathrm{a}}$ & $1,271^{\mathrm{b}}$ & 227 \\
Feed cost/gain, \% & 100 & 54.6 & - \\
Break-even cost, won/kg & - & 147 & - \\
\hline
\end{tabular}

${ }^{1)}$ Based on formulated feed $=221 \mathrm{won} / \mathrm{kg}$, rice straw = $180 \mathrm{won} / \mathrm{kg}$, mixed ration $=70 \mathrm{won} / \mathrm{kg}$ (broiler litter $=$ $30 \mathrm{won} / \mathrm{kg}$, bakery by-product $=150 \mathrm{won} / \mathrm{kg}$ ).

${ }^{2)}$ Mixed ration $90 \%$ : rice straw $10 \%$; Mixed ration = Broiler litter $64 \%$ : bakery by-product $36 \%$ on DM basis.

${ }^{\mathrm{a}, \mathrm{b}}$ Means with different superscripts within the same row differ $(\mathrm{I}<0.05)$.

사료섭취량과 일당증체율은 비슷하였으며, 증 체당 사료비 절감효과는 30 $1 \%$ 정도였다. 이 러한 결과와 비교해볼 때 본 연구의 사료비 절 감 효과는 상당한 것으로 사료되었다. 이때 대 조구 사료와 비교한 시험구 사료의 손익분기점 가격(break-even cost)은 147 원 $/ \mathrm{kg}$ 인 것으로 계산 되었다. 즉 이 수준 이하로 현장 시장 가격이 형성될 때만이 대체 효과가 나타남을 의미하 며, 이는 현장에서의 실제 이용 시에 우선적으 로 고려하여야 할 사항이다.

결과적으로 한우 육성우의 기존의 배합사료볏짚 급여 체계와 비교해서 육계분-제과부산물 로 제조된 혼합사료의 급여 체계는 한우 육성 우의 생산성을 양호한 상태로 유지하면서 상당 한 수준(40\%대 수준)의 사료비 절감 효과를 누 리는 것으로 나타났다.

\section{5. 고기 특성}

거세 한우의 육성기 12 주간의 혼합사료 급여 가 최종 비육 후 도축 시의 육 특성에 미치는 영향은 Table 6에 제시되어져 있다. 대조구와 비교해서 시험구 사료 급여는 등지방 두께, 등 심 단면적, 육질 및 육량 등급, 육량 지수, 근 내 지방도, 육색, 지방색, 조직감, 성숙도 등에 유의한 영향을 미치지 않았다. 처리별 총 등급 은 대조구 4 두는 각각 $\mathrm{C1}^{+}, \mathrm{A} 1, \mathrm{~A} 2, \mathrm{~B} 2$ 수준을
보였고, 시험구 5 두는 각각 $\mathrm{A1}^{+}, \mathrm{A} 1^{+}, \mathrm{A} 1, \mathrm{~A} 2$, B3 수준을 보였다. 즉 육질 및 육량 등급에 있 어서 시험구 사료 급여는 대조구와 비교해서 전 혀 나쁘지 않은 결과를 보여주었다. 또한 육성기 12 주 동안의 육계분 급여는 육 특성에 아무런 영 향을 미치지 않았고, 특히 제과부산물의 높은 지 방 성분은 도살 후의 등지방 두께, 지방색, 근내 지방도 등의 지방 관련 특성에 영향을 미치지 않 은 것으로 나타났다. 이는 본 연구에서 제조된 육계분-제과부산물 혼합사료의 급여는 최종 육 특성에 영향을 미칠 정도의 장기간의 사양이 아 니었기 때문일 수도 있다. 유사한 국내 연구(곽, 2000)에서도 발효 육계분을 Holstein 비육우에게 급여하였을 때 육 특성에 현저한 영향을 미치지 않았다. 미국의 경우, 방목 중인 육성우에게 육계 분을 급여하였을 때 도살 시의 근내 지방도, 등 지방 두께, 등심 단면적, 육량 및 육질 등은 전혀 나쁜 영향를 받지 않았다(Davis 등, 1995). 일반적 으로 축분 급여는 육, 유, 란의 맛에도 영향을 미 치지 않는 것으로 보고된 바 있다(Fontenot와 Jurubescu, 1980). 향후 현장 농장에서 본 혼합사 료를 이용한 장기간 사양 실험을 통한 육 특성 확인 과정이 요구되어진다.

Table 6. Meat grade and quality after slaughtering of 'Hanwoo' steers fed different diets during the 12 wk of growing period $^{1)}$

\begin{tabular}{lrrr}
\hline \multicolumn{1}{c}{ Item } & Control & Treatement $^{2)}$ & SE \\
\hline \hline Back fat, mm & 9.3 & 9.0 & 1.4 \\
Rib-eye area, cm & 81.5 & 88.2 & 7.7 \\
Quality grade & 1.2 & 1.3 & 0.7 \\
Meat quantity index & 68.2 & 69.2 & 0.8 \\
Marbling score & 4.3 & 4.2 & 1.4 \\
Meat color & 4.8 & 4.8 & 0.3 \\
Fat color & 2.8 & 3.0 & 0.2 \\
Texture & 1.5 & 1.4 & 0.4 \\
Maturity & 2.3 & 2.0 & 0.2 \\
\hline
\end{tabular}

${ }^{1)}$ Means of 4 observations for control and means of 5 observations for TMR.

${ }^{2)}$ Mixed ration $90 \%$ : rice straw $10 \%$; mixed ration = Broiler litter $64 \%$ : bakery by-product $36 \%$ on DM basis.

${ }^{a, b}$ Means with different superscripts within the same row differ(I $<0.05)$. 
덧붙여, 본 실험에서 이용된 혼합사료의 현 장 사양 효과를 보다 향상시키기 위해서 부족 한 비타민 $\mathrm{A}$ 를 사료에 첨가 또는 근육주사를 통해 별도로 공급해 주거나, 미네랄-비타민 block를 우사 내에 비치해 주는 것도 생산성 향상에 도움이 될 것으로 사료되었다. 왜냐하 면 육계분에는 비타민 $\mathrm{A}$ 가 거의 없는 것으로 알려져 있다(Ruffin과 McCaskey, 1990; Bagley와 Evans, 1995). 그리고 고급육 생산을 위해 비육 기간 중 비타민 $\mathrm{A}$ 결핍 현상을 인위적으로 유 도하는 기술에도 효과적으로 이용될 가능성이 있을 수 있다.

\section{IV 결 론}

육성 거세 한우 사양 실험 결과, 기존의 배 합사료-볏짚 급여 체계와 비교해서 본 연구에 서 동일 사료 에너지 수준으로 제조된 육계분제과부산물 혼합사료 $90 \%$ 와 볏짚 $10 \%(\mathrm{DM}$ 기 준)의 급여는 생산성을 유지하면서, 상당한 (40\% 대) 사료비 절감 효과를 보여주었고, 육 등급 및 육질에는 전혀 나쁜 영향을 미치지 않 았다. 결과적으로 본 혼합사료는 영양적으로 한우 육성기의 목표 증체율(0.6 $7 \mathrm{~kg} /$ 일)을 만족시킬 정도의 양호한 영양적 가치를 보유하 는 것으로 나타났다. 혼합사료 제조 시에 제과 공장에서 대량으로 배출되는 제과폐기물을 영 농단체나 대규모 농장에서 바로 구입해서 육계 분과의 퇴적발효 방법을 통해 위생적으로 처리 한다면 제과폐기물의 건조 비용을 절약함과 동 시에 사료비 절감 효과는 더욱 증대할 것이다. 향후 현장 농장에서 본 혼합사료를 이용한 축 종별 생리단계별 대규모 장기간 사양 실험이 요구되어진다.

\section{$\mathrm{V}$ 요 약}

본 연구는 개발된 육계분(64\%)-제과부산물 (36\%) 혼합사료 $90 \%$ 와 볏짚 $10 \%$ 로의 기존의 배합사료와 볏짚 완전 대체 시 육성 거세 한우 의 생산성, 경제성 및 육 특성에 미치는 효과 를 구명하고자 실시하였다. 동일 열량 기준으
로 설계된 대조구와 시험구 사료를 육성 한우 총 20 두에게 12 주간 급여한 결과는 다음과 같 았다. 제조된 혼합사료의 성분 변이도는 배합 사료보다 높은 편이었으며, 혼합사료의 기호성 문제는 없었다. 혼합사료 $90 \%$-볏짚 $10 \%$ 급여 구(시험구)는 기존의 배합사료-볏짚 급여구(대 조구)와 비교해서 사료 $\mathrm{DM}$ 섭취량은 높았고 ( $<0.05), \mathrm{OM}$ 섭취량은 동일하였으며, 일당증 체율(0.75 vs $0.64 \mathrm{~kg} / \mathrm{d})$ 과 $\mathrm{DM}(10.1$ vs 12.5$)$, $\mathrm{OM}(9.0$ vs 10.6) 사료 효율 또한 비슷하였다. 혼합사료 급여는 증체 당 사료비용을 약 $45 \%$ 절감시켰으며, 육 특성에는 전혀 나쁜 영향을 미치지 않았다. 이러한 결과들은 육계분-제과 부산물 혼합사료는 한우 육성용으로서 성공적 으로 이용될 수 있는 잠재적 가능성을 시사하 고 있다.

\section{$\mathrm{VI}$ 사 사}

본 연구는 농림부 기획연구 지원에 의해 수 행되었다. 저자들은 화학 분석과 현장 사양 실 험을 부분적으로 지원해 준 건국대학교 폐자원 사료실의 백용현, 김영일, 지경수 군들에게 감 사를 표한다.

\section{VII 인 용 문 헌}

1. AOAC. 1990. Official Methods of Analysis (15th Ed.). Association of Official Analytical Chemists, Washington, D. C.

2. Bagley, C. P. and Evans, R. R. 1995. Broiler litter as fertilizer or feed in livestock operations. Mississippi Coop. Ext. Serv. Bull. 1998, USA.

3. Cross, D. L. and Jenny, B. F. 1975. Turkey litter silage in ration for dairy heifers. J. Dairy Sci. 59 (5):919-923.

4. Davis, G. V., Troxel, T. R., Burke, G. L. and Duncan, R. L. 1995. Supplemental corn and broiler litter for stocker calves on legume-grass pastures and subsequent feedlot performance. J. Anim. Sci. vol. 73 (Suppl.):5(Abstr.).

5. Ensminger, M. E., Oldfield, J. E. and Heinemann, W. W. 1990. Feed and Nutrition (2nd ed.). The Ensminger Publishing Company, Clovis, California, USA. 
6. Fontenot, J. P. and Jurubescu, V. 1980. Processing of animal waste by feeding to ruminants. In: Ruckebusch, Y. and Thivend, P.(Ed.) : Digestive Physiology and Metabolism in Ruminants. AVI Publishing Co., Inc., Westport, CT. p. 641-664, USA.

7. Guiroy, P. J., Fox, D. G., Beermann, D. H. and Ketchen, D. J. 2000. Performance and meat quality of beef steers fed corn-based or bread by-productbased diets. J. Anim. Sci. 78:784-790.

8. McCaskey, T. A., Britt, S. N., Ruffin, B. G. and Eason, J. T. 1994a. Performance and economic value of a poultry litter-based diet for beef stocker production. J. Anim. Sci. Vol. 72 (Suppl. 1):137.

9. McCaskey, T. A., Britt, S. N., Ruffin, B. G. and Eason, J. T. 1994b. Feed value of broiler litter for stocker cattle. Highlights of Alabama Agric. Res. 41(1):12.

10. Milton, C. T. and Brandt, R. T. Jr. 1994. Dried bakery product in high concentrate rations: Finishing steer performance and estimated net energy values. J. Anim. Sci. 72(Suppl. 2):80(Abstr.).

11. Rankins, D. L. 1995. Processing options for broiler litter. Feed Mix 3(1):8-11.

12. Ruffin, B. G. and McCaskey, T. A. 1990. Broiler litter can serve as a feed ingredient for beef cattle. Feedstuffs 62(15):13-17.
13. Statistix7. 2000. User's Manual. Analytical Software, Tallahassee, FL, USA.

14. Van Soest, P. J., Robertson, J. B. and Lewis, B. A. 1991. Methods of dietary fiber, neutral detergent fiber, and nonstarch polysaccharides in relation to animal nutrition. J. Dairy Sci. 74:3583.

15. 고영두, 송영민, 강한석, 김두환. 1991. 계분과 당 밀을 첨가한 볏짚 silage의 품질과 사료적 가치 II. Silage의 소화율과 기호성. 한축지 33(3):233-237.

16. 곽완섭. 2000. Biohull(육계분-왕겨)사료의 고부가 가치화 및 동물산업적 활용에 관한 연구. 3 차년 도 최종보고서, 농림부.

17. 곽완섭, 윤정식, 정근기. 2003. 육계분과 제과부산 물을 이용한 반추가축용 완전혼합사료(TMR) 제 조 시 가공처리 방법이 물리화학적 특성에 미치 는 영향. 한국동물자원과학회지, 투고 중.

18. 노경상. 2001. 남은음식물사료에 대한 안전관리 제도. 남은음식물 안전 사료화 이용기술에 대한 제5회 심포지움, pp 3-33, 농촌진흥청 축산 기술 연구소.

19. 농촌진흥청. 1992. 한국표준가축사료급여기준(한 우). 한국가축사양표준제정위원회.

20. 이보균, 곽완섭. 1999. 육계분펠렛사료 함유 배합 사료에의 한우 기호성 검사. 건국자연과학연구지 10(1):17-22.

(접수일자 : 2003. 2. 24. / 채택일자 : 2003. 8. 22.) 